University of Nebraska - Lincoln

DigitalCommons@University of Nebraska - Lincoln

Mechanical \& Materials Engineering Faculty

Publications

Mechanical \& Materials Engineering,

Department of

2006

\title{
Efficient inverted polymer solar cells
}

G. Li

University of California, Los Angeles

C.-W. Chu

University of California, Los Angeles

V. Shrotriya

University of California at Los Angeles

Jinsong Huang

University of Nebraska-Lincoln, jhuang@unc.edu

Y. Yang

University of California at Los Angeles

Follow this and additional works at: https://digitalcommons.unl.edu/mechengfacpub

Part of the Mechanics of Materials Commons, Nanoscience and Nanotechnology Commons, Other Engineering Science and Materials Commons, and the Other Mechanical Engineering Commons

Li, G.; Chu, C.-W.; Shrotriya, V.; Huang, Jinsong; and Yang, Y., "Efficient inverted polymer solar cells" (2006). Mechanical \& Materials Engineering Faculty Publications. 175.

https://digitalcommons.unl.edu/mechengfacpub/175

This Article is brought to you for free and open access by the Mechanical \& Materials Engineering, Department of at DigitalCommons@University of Nebraska - Lincoln. It has been accepted for inclusion in Mechanical \& Materials Engineering Faculty Publications by an authorized administrator of DigitalCommons@University of Nebraska Lincoln. 


\title{
Efficient inverted polymer solar cells
}

\author{
G. Li, C.-W. Chu, V. Shrotriya, J. Huang, and Y. Yang ${ }^{a)}$ \\ Department of Materials Science and Engineering, University of California at Los Angeles, Los Angeles, \\ California 90095-1595
}

(Received 24 January 2006; accepted 28 April 2006; published online 21 June 2006)

\begin{abstract}
We investigate the effect of interfacial buffer layers-vanadium oxide $\left(\mathrm{V}_{2} \mathrm{O}_{5}\right)$ and cesium carbonate $\left(\mathrm{Cs}_{2} \mathrm{CO}_{3}\right)_{-}$on the performance of polymer solar cells based on regioregular poly-(3-hexylthiophene) and [6,6]-phenyl C60 butyric acid methyl ester blend. The polarity of solar cells can be controlled by the relative positions of these two interfacial layers. Efficient inverted polymer solar cells were fabricated with the structure of indium tin oxide (ITO) $/ \mathrm{Cs}_{2} \mathrm{CO}_{3} /$ polymer blend/vanadium oxide $\left(\mathrm{V}_{2} \mathrm{O}_{5}\right)$ /aluminum $(\mathrm{Al})$. Short-circuit current of $8.42 \mathrm{~mA} / \mathrm{cm}^{2}$, open-circuit voltage of $0.56 \mathrm{~V}$, and power conversion efficiency of $2.25 \%$ under a AM1.5G $130 \mathrm{~mW} / \mathrm{cm}^{2}$ condition were achieved. The interfacial layers were also used to fabricate polymer solar cells using ITO and a thin gold $(\mathrm{Au})$ layer as the transparent electrodes. The thickness of $\mathrm{V}_{2} \mathrm{O}_{5}$ layer $(10 \mathrm{~nm})$ makes it an effective protective layer for the active layer so that ITO can be used for both the electrodes, enabling highly efficient transparent polymer solar cells (i.e., polymer solar cells with transparent electrodes). Application of this structure for multiple-stacking polymer solar cells is also discussed. (C) 2006 American Institute of Physics. [DOI: 10.1063/1.2212270]
\end{abstract}

Fast improvement in polymer solar cells (PSCs) performance in recent years ${ }^{1,2}$ has distinguished this technology as a promising cost effective alternative to silicon based solar cells. PSCs can be utilized to generate truly clean and renewable energy from sunlight. Recently, our group demonstrated very efficient polymer solar cells with $4.4 \%$ power conversion efficiency ${ }^{3}$ (PCE) in regioregular poly-(3hexylthiophene) (RR-P3HT) and [6,6]-phenyl C60 butyric acid methyl ester (PCBM) bulk-heterojunction (BHJ) structure. ${ }^{4}$ While the external quantum efficiency of polymer solar cells is approaching that of their inorganic semiconductor counterparts, ${ }^{2,3,5}$ limited absorption in solar spectrum remains a major limitation to achieve high PCE. To solve this problem, it is widely accepted that multiple polymer solar cells in tandem, covering different spectral regions, must be used. However, it is generally not easy to realize multiple polymer films in tandem without destroying the underlying polymer layer(s). An alternative approach is to fabricate efficient transparent polymer solar cells (i.e., polymer solar cells with transparent electrodes) with different spectral responses and stack them together.

Deposition of transparent conducting oxides (TCOs) for minimal light loss normally requires sputtering process, which severely damages the underlying organic layers. A suitable interfacial layer can, however, be used to protect the underlying organic layers. Functional interfacial buffer layers $\left(\mathrm{LiF}^{6}{ }^{\mathrm{CsF}}{ }^{7}\right.$ and $\mathrm{AlO}_{x}$ ) have been intensively studied during the development of organic light-emitting devices (OLEDs). $\mathrm{LiF}$ has also been reported to enhance polymer solar cell efficiency. ${ }^{9}$ However, the required small thickness $(<2 \mathrm{~nm})$ provides insufficient protection of the underlying organic active materials. It was recently demonstrated that some transition metal oxides [e.g., vanadium oxide $\left(\mathrm{V}_{2} \mathrm{O}_{5}\right)$, molybdenum oxide $\left.\left(\mathrm{MoO}_{3}\right)\right]$ can be used to replace poly(ethylenedioxythiophene) doped with poly(styrenesulfonate) (PEDOT:PSS) as the anodic buffer layer in polymer solar cells ${ }^{10}$ and as an interfacial layer in organic thin-

\footnotetext{
${ }^{a)}$ Electronic mail: yangy@ucla.edu
}

film transistors. ${ }^{11}$ These metal oxides are highly transparent, and the device photocurrent is unaffected even when the oxide thickness is up to $20 \mathrm{~nm}$. In an inverted polymer solar cell structure, these metal oxides can provide sufficient protection to the active organic layer while maintaining good device performance. In this letter, we first demonstrate an enhancement in polymer solar cell efficiency by using cesium carbonate $\left(\mathrm{Cs}_{2} \mathrm{CO}_{3}\right)$ interfacial buffer layer at the cathode. We then show that the polarity of solar cells can be reversed by changing the position of $\mathrm{V}_{2} \mathrm{O}_{5}$ (hole injection) and $\mathrm{Cs}_{2} \mathrm{CO}_{3}$ (electron injection) interfacial layers, independent of the top and bottom electrodes. An efficient inverted polymer solar cell can be fabricated with the device structure: ITO/Cs ${ }_{2} \mathrm{CO}_{3} / \mathrm{P} 3 \mathrm{HT}$ :PCBM/ $\mathrm{V}_{2} \mathrm{O}_{5} /$ metal. Additionally, a thin Au layer is used as the top transparent electrode to fabricate transparent polymer solar cells.

Conventional device fabrication processes were described before. ${ }^{3}$ Active layer of $\sim 65 \mathrm{~nm}$ was spun-coated from RR-P3HT/PCBM 1:1 wt-ratio ${ }^{12,13}$ solution $(20 \mathrm{mg} / \mathrm{ml}$ each in dichlorobenzene) at $3500 \mathrm{rpm}$, followed by annealing at $110{ }^{\circ} \mathrm{C}$ for $10 \mathrm{~min} .{ }^{14} \mathrm{~V}_{2} \mathrm{O}_{5}(10 \mathrm{~nm}), \mathrm{Cs}_{2} \mathrm{CO}_{3}(1 \mathrm{~nm})$, and $\mathrm{LiF}(1 \mathrm{~nm})$ were thermally evaporated at the rate of about $0.02 \mathrm{~nm} / \mathrm{s}$. Solution process $\mathrm{Cs}_{2} \mathrm{CO}_{3}$, was described elsewhere. ${ }^{17}$ The schematic of device structure in shown in Fig. 1. Thermo-Oriel $150 \mathrm{~W}$ solar simulator with AM1.5G filter provides $130 \mathrm{~mW} / \mathrm{cm}^{2}$ illumination, determined by a NREL calibrated Si-detector (with KG-5 color filter) and spectral mismatch is corrected.

Research on functional interfacial materials is a very active area in the field of organic electronic devices. $\mathrm{LiF}$ is an effective cathode interfacial layer for both polymer based LEDs ${ }^{15}$ and solar cells. ${ }^{9} \mathrm{Cs}_{2} \mathrm{CO}_{3}$ is a relatively new interfacial material, first reported for OLED applications by Canon group. ${ }^{16}$ Unlike LiF, in an OLED the function of $\mathrm{Cs}_{2} \mathrm{CO}_{3}$ is insensitive to the metal electrode above it. Our group has demonstrated white polymer light-emitting diode (PLED) with $16 \mathrm{~lm} / \mathrm{W}$ efficiency using this method. ${ }^{17}$ In Fig. 2, the $J-V$ curves for four different polymer solar cells are shown, with different interfacial layers at the ITO and Al interfaces. 


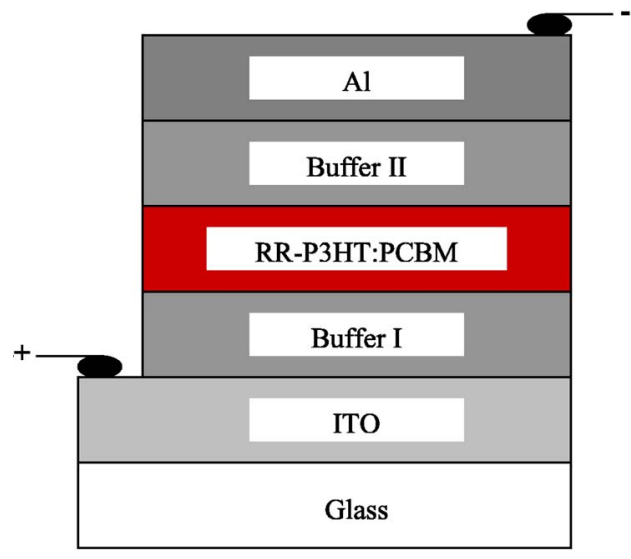

FIG. 1. (Color online) (a) Schematic of the device structure of polymer solar cell fabricated in this study and (b) the molecular structures of active materials in polymer solar cell-RR-P3HT and PCBM.

In the device with no buffer layer (ITO/blend/Al), reasonable photovoltaic effect was observed with short-circuit current density $\left(J_{\mathrm{SC}}\right)$ of $4.75 \mathrm{~mA} / \mathrm{cm}^{2}$. However, open-circuit voltage $\left(V_{\mathrm{OC}}\right)$ and fill factor $(\mathrm{FF})$ are poor at $0.22 \mathrm{~V}$ and $28.5 \%$, resulting in PCE of only $0.23 \%$. Modifying the ITO anode by PEDOT:PSS provides significant improvement in the device performance where $J_{\mathrm{SC}}$ increases to $7.44 \mathrm{~mA} / \mathrm{cm}^{2}, V_{\mathrm{OC}}$ to $0.42 \mathrm{~V}, \mathrm{FF}$ to $51.8 \%$, and the overall efficiency to $1.25 \%$. Furthermore, insertion of $1 \mathrm{~nm}$ thermally evaporated $\mathrm{Cs}_{2} \mathrm{CO}_{3}$ layer at the polymer/Al interface leads to a reduction in $J_{\mathrm{SC}}$ at $5.95 \mathrm{~mA} / \mathrm{cm}^{2}$. However, the $V_{\mathrm{OC}}$ increases to $0.52 \mathrm{~V}$, and an excellent FF of $65.6 \%$ is achieved. This results in a PCE of $1.55 \%$, a $25 \%$ improvement. These results clearly show that $\mathrm{Cs}_{2} \mathrm{CO}_{3}$ can act as a functional interfacial layer to enhance polymer solar cell efficiency. The work function of PEDOT:PSS is $5.0 \mathrm{eV}$, which is $0.3 \mathrm{eV}$ higher than that of ITO $(4.7 \mathrm{eV})$. This work-function increase can explain the increase in $V_{\mathrm{OC}}$ by $0.2 \mathrm{eV}$ according to the metalinsulator-metal (MIM) model. ${ }^{18}$ This apparently contradicts the common belief that the energy level difference between the donor highest occupied molecular orbital (HOMO) and the acceptor lowest unoccupied molecular orbital (LUMO) levels dominates ${ }^{19}$ the $V_{\mathrm{OC}}$ in the polymer BHJ solar cell. However, the contact changes from non-Ohmic in the case of ITO to Ohmic for PEDOT:PSS, and both electrodes being $\mathrm{Ohmic}^{20}$ is a necessary condition for the above belief to be valid. Earlier study on $\mathrm{Cs}_{2} \mathrm{CO}_{3}$ indicated that during thermal

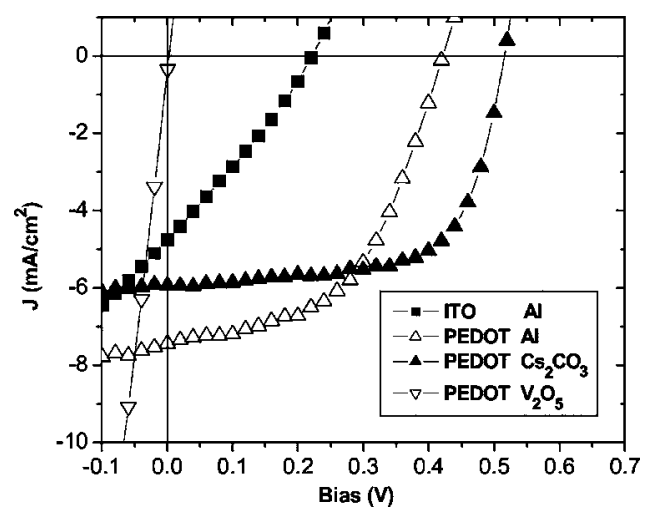

FIG. 2. The effect of interfacial layers on the performance of conventional polymer solar cells. The interfacial layers at ITO/blend and blend/Al interfaces are (a) none, none (solid square); (b) PEDOT:PSS, none (open triangle); (c) PEDOT:PSS, $\mathrm{Cs}_{2} \mathrm{CO}_{3}$ (solid triangle); and (d) PEDOT:PSS, $\mathrm{V}_{2} \mathrm{O}_{5}$ (open inverted triangle). The light intensity is $130 \mathrm{~mW} / \mathrm{cm}^{2}$.
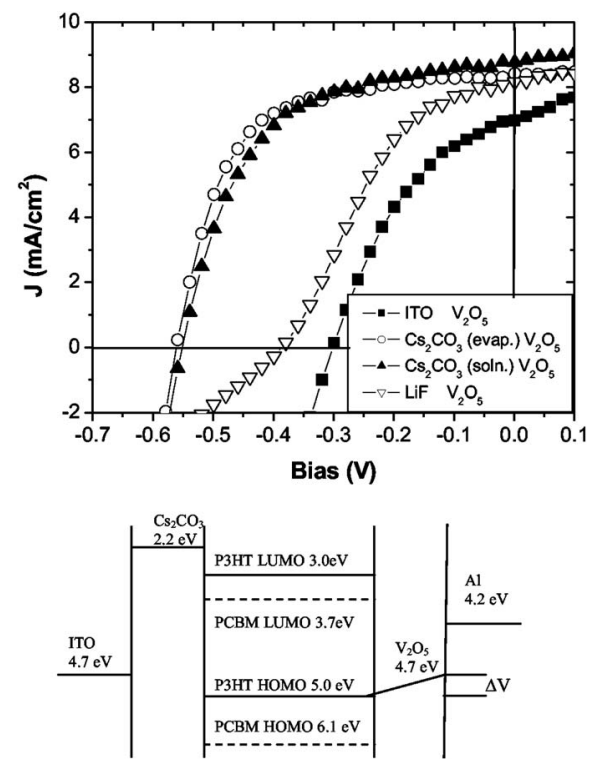

FIG. 3. (a) Current-voltage characteristics of inverted polymer solar cells. The interfacial layers at ITO/blend and blend/Al interfaces are (i) none, $\mathrm{V}_{2} \mathrm{O}_{5}$ (solid square); (ii) $\mathrm{Cs}_{2} \mathrm{CO}_{3}$ (evaporated), $\mathrm{V}_{2} \mathrm{O}_{5}$ (open circle); (iii) $\mathrm{Cs}_{2} \mathrm{CO}_{3}$ (solution process), $\mathrm{V}_{2} \mathrm{O}_{5}$ (solid triangle); and (iv) $\mathrm{LiF}, \mathrm{V}_{2} \mathrm{O}_{5}$ (open inverted triangle). (b) Energy level diagrams for various materials in the inverted solar cells.

evaporation, $\mathrm{Cs}_{2} \mathrm{CO}_{3}$ decomposes into cesium oxide. Depending on the film thickness, the resulting cesium oxide has a field-emission work function of $\sim 1.1 \mathrm{eV}^{21}$ because of thermoionic emission. Ultraviolet photoemission spectroscopy (UPS) measurements conducted in our laboratory on thermally evaporated $\mathrm{Cs}_{2} \mathrm{CO}_{3}$ films show a work function of $2.2 \mathrm{eV}{ }^{22}$ The polymer/ $\mathrm{Cs}_{2} \mathrm{CO}_{3}$ contact is therefore Ohmic. An increase in $V_{\mathrm{OC}}$ by only $0.1 \mathrm{~V}$, despite the work-function difference between $\mathrm{Cs}_{2} \mathrm{CO}_{3}$ and $\mathrm{Al}$ of $2 \mathrm{eV}$, agrees well with the earlier observation by Brabec et al. ${ }^{19}$ and indicates Fermi-level pinning. The ITO/ $\mathrm{V}_{2} \mathrm{O}_{5} /$ blend/Al device shows the same polarity as that of ITO/PEDOT:PSS/blend/Al device. The $V_{\mathrm{OC}}$ for the former ( $J-V$ curve not shown here) is $0.38 \mathrm{eV}$, also significantly higher compared to bare ITO electrode. The HOMO level of a thermally evaporated $\mathrm{V}_{2} \mathrm{O}_{5}$ film was determined by UPS to be $4.7 \mathrm{eV}$ which is identical to that of ITO. The most plausible reason for $V_{\mathrm{OC}}$ enhancement is the formation of surface dipoles between $\mathrm{V}_{2} \mathrm{O}_{5}$ and an active layer, which causes an upward shift in work function of at least $0.2 \mathrm{eV}$. These results indicate that $\mathrm{V}_{2} \mathrm{O}_{5}$ can be considered as an effective hole injection layer, like PEDOT:PSS, with a similar effective work function. This is further evidenced by the $J$ - $V$ curves for an ITO/PEDOT:PSS/ polymer blend $/ \mathrm{V}_{2} \mathrm{O}_{5} / \mathrm{Al}$ device, where no photovoltaic effect was observed (see Fig. 2). The anode contact therefore has an important effect on polymer solar cell performance.

Figure 3 shows $J$ - $V$ curves for various inverted polymer solar cell structures. The ITO/polymer blend/ $\mathrm{V}_{2} \mathrm{O}_{5}(10 \mathrm{~nm}) / \mathrm{Al}$ inverted solar cell has $J_{\mathrm{SC}}=6.97 \mathrm{~mA} / \mathrm{cm}^{2}$, $V_{\mathrm{OC}}=0.30 \mathrm{~V}, \mathrm{FF}=41.2 \%$, and PCE of $0.66 \%$. This provides further evidence for the presence of surface dipoles that enhance the $\mathrm{V}_{2} \mathrm{O}_{5}$ work function by $\sim 0.3 \mathrm{eV}$. Based on the results so far, an efficient inverted polymer solar cell can be achieved with the structure ITO/ $\mathrm{Cs}_{2} \mathrm{CO}_{3} /$ polymer blend/ $\mathrm{V}_{2} \mathrm{O}_{5} / \mathrm{Al}$, where $\mathrm{Cs}_{2} \mathrm{CO}_{3}$ was either thermally evaporated or spin coated. The $J-V$ curves in Fig. 3 for solar cells with thermally evaporated (1 nm, open circle) and solution pro- 


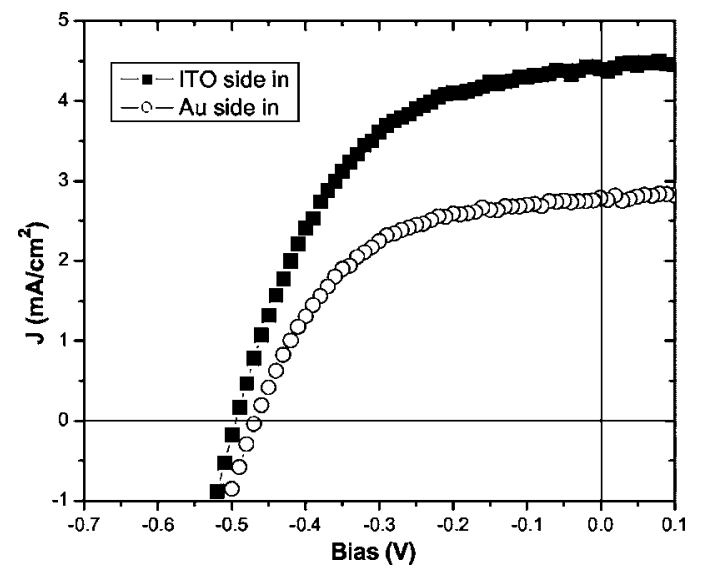

FIG. 4. I-V curves for transparent polymer solar cells illuminated from two transparent electrodes-ITO and $\mathrm{Au}$.

cessed (solid triangle) $\mathrm{Cs}_{2} \mathrm{CO}_{3}$ clearly demonstrate efficient inverted solar cells. The $J_{\mathrm{SC}}, V_{\mathrm{OC}}$, and FF are very similar for the evaporated $\left(8.42 \mathrm{~mA} / \mathrm{cm}^{2}, 0.56 \mathrm{~V}\right.$, and $\left.62.1 \%\right)$ and the solution processed $\left(8.78 \mathrm{~mA} / \mathrm{cm}^{2}, 0.55 \mathrm{~V}\right.$, and $\left.56.3 \%\right)$ device. The overall efficiencies are $2.25 \%$ and $2.10 \%$, respectively. Therefore, inserting $\mathrm{V}_{2} \mathrm{O}_{5}$ and $\mathrm{Cs}_{2} \mathrm{CO}_{3}$ interfacial layers can result in efficient conventional as well as inverted polymer solar cells. $\mathrm{LiF}$ (1 nm, electron injection layer) and $\mathrm{V}_{2} \mathrm{O}_{5}(10 \mathrm{~nm}$, hole injection layer) were also used to fabricate inverted solar cells. This device has a current density comparable to the device with $\mathrm{Cs}_{2} \mathrm{CO}_{3}$ and $\mathrm{V}_{2} \mathrm{O}_{5}$, but an antidiode behavior results in low $V_{\mathrm{OC}}(0.39 \mathrm{~V}), \mathrm{FF}(40.7 \%)$, and PCE $(0.99 \%)$. A thin LiF layer has been reported to work well with a wide range of metals $(\mathrm{Ca}, \mathrm{Al}$, and $\mathrm{Au})$ in conventional device configuration. The presence of an antidiode in the inverted configuration indicates that the $\mathrm{LiF}$ growth pattern (on ITO versus on polymer) might have a significant impact on device performance.

In conventional device structure, introducing $1 \mathrm{~nm}$ thermally evaporated $\mathrm{Cs}_{2} \mathrm{CO}_{3}$ reduces the device photocurrent but improves $V_{\mathrm{OC}}$ and FF significantly, indicating possible physical damage. However, in the inverted structure, where $\mathrm{Cs}_{2} \mathrm{CO}_{3}$ is deposited on ITO substrates, all three parameters are improved.

Based on information collected, we can treat $\mathrm{V}_{2} \mathrm{O}_{5}$ as a hole injection layer with "effective" work function of $\sim 5.0 \mathrm{eV}$ and $\mathrm{Cs}_{2} \mathrm{CO}_{3}$ as an electron injection layer with very low work function, both of which provide Ohmic contacts. The polarity of the device is decided by the relative positions of these two interfacial layers and is insensitive to the conducting electrodes. The energy level diagrams for various inverted configurations are illustrated in Fig. 3(b).

Due to the presence of a thick $(10 \mathrm{~nm}) \mathrm{V}_{2} \mathrm{O}_{5}$ layer which protects the underlying polymer, the inverted configuration is especially suitable for making transparent solar cells. We replaced a thick $\mathrm{Al}$ top electrode with $12 \mathrm{~nm}$ of $\mathrm{Au}$ in the inverted structure. The $J-V$ curves for this transparent polymer solar cell, with light incident from ITO and the Au side, are shown in Fig. 4. When illuminated from the ITO side, the device shows an overall efficiency of $0.85 \%$. However, when illuminated from the semitransparent Au electrode, the PCE is $0.52 \%$. The difference between the two $J$ - $V$ curves is due to the partial loss by the reflection and absorption at the semitransparent Au electrode. In a transparent solar cell, the light absorption is less than that in a device with a reflecting metal electrode. Similar to inorganic solar cells, the $V_{\mathrm{OC}}$ of organic solar cells also increases with increasing incident light intensity. The slight reduction in the $V_{\mathrm{OC}}$ of transparent solar cells can therefore be explained by the less effective light intensity. When designing a tandem polymer solar cell, the optical losses due to the first transparent solar cell should be reduced. To provide sufficient electrical conductance, $\mathrm{Au}$ layer thickness has to be sufficient and the optical loss at $\mathrm{Au}$ electrode becomes significant. However, the inverted solar cell structure has a metal oxide layer that is not only transparent but also provides effective protection to the polymer layer. A transparent conductive oxide electrode, such as ITO, can therefore be deposited without compromising device performance. This structure thus provides a very efficient method for realizing tandem polymer solar cells for improving device efficiency.

To summarize, we have fabricated efficient conventional and inverted polymer solar cells by using different functional interfacial layers. Efficiency up to $2.25 \%$ has been achieved for an inverted polymer solar cell with FF as high as $62.1 \%$. Preliminary efforts have also demonstrated transparent polymer solar cells with $0.85 \%$ efficiency.

The financial support is provided by the Office of Naval Research (ONR) (Grant No. N00014-04-1-0434).

${ }^{1}$ S. E. Shaheen, C. J. Brabec, N. S. Sariciftci, F. Padinger, T. Fromherz, and J. C. Hummelen, Appl. Phys. Lett. 78, 841 (2001).

${ }^{2}$ F. Padinger, R. S. Rittberger, and N. S. Sariciftci, Adv. Funct. Mater. 13, 85 (2003).

${ }^{3}$ G. Li, V. Shrotriya, J. Huang, Y. Yao, and Y. Yang, Nat. Mater. 4, 864 (2005).

${ }^{4}$ N. S. Sariciftci, L. Smilowitz, A. J. Heeger, and F. Wudl, Science 258, 1474 (1992).

${ }^{5}$ P. Schilinsky, C. Waldauf, and C. J. Brabec, Appl. Phys. Lett. 81, 3885 (2002).

${ }^{6}$ L. S. Hung, C. W. Tang, and M. G. Mason, Appl. Phys. Lett. 70, 152 (1997).

${ }^{7}$ G. E. Jabbour, B. Kippelen, N. R. Amstrong, and N. Peyghambarian, Appl. Phys. Lett. 73, 1185 (1998).

${ }^{8}$ F. Li, H. Tang, J. Anderegg, and J. Shinar, Appl. Phys. Lett. 70, 1233 (1997).

${ }^{9}$ C. J. Brabec, S. E. Shaheen, C. Winder, N. S. Sariciftci, and P. Denk, Appl. Phys. Lett. 80, 1288 (2002).

${ }^{10}$ V. Shrotriya, G. Li, Y. Yao, C.-W. Chu, and Y. Yang, Appl. Phys. Lett. 88, 073508 (2006).

${ }^{11}$ C. W. Chu, C. W. Chen, S. H. Li, E. H. Wu, and Y. Yang, Appl. Phys. Lett. 86, 253503 (2005).

${ }^{12}$ V. Shrotriya, J. Ouyang, R. J. Tseng, G. Li, and Y. Yang, Chem. Phys. Lett. 411, 138 (2005).

${ }^{13}$ D. Chirvase, J. Parisi, J. C. Hummelen, and V. Dyakonov, Nanotechnology 15, 1317 (2004).

${ }^{14}$ G. Li, V. Shrotriya, Y. Yao, and Y. Yang, J. Appl. Phys. 98, 043704 (2005).

${ }^{15}$ T. M. Brown, R. H. Friend, I. S. Millard, D. J. Lacey, J. H. Burroughes, and F. Cacialli, Appl. Phys. Lett. 79, 174 (2001).

${ }^{16}$ T. Hasegawa, S. Miura, T. Moriyama, T. Kimura, I. Takaya, Y. Osato, and H. Mizutani, Dig. Tech. Papers-Soc. Inf. Disp. Int. Symp. 35, 154 (2004).

${ }^{17}$ J. Huang, G. Li, E. Wu, Q. Xu, and Y. Yang, Adv. Mater. (Weinheim, Ger.) 18, 144 (2006).

${ }^{18}$ I. D. Parker, J. Appl. Phys. 75, 1656 (1994).

${ }^{19}$ C. J. Brabec, A. Cravino, T. Fromherz, N. S. Saricifici, M. Minse, L. Sanchez, and J. C. Hummelen, Adv. Funct. Mater. 11, 374 (2001).

${ }^{20}$ V. D. Mihailetchi, P. W. M. Blom, J. C. Hummelen, and M. T. Rispens, Appl. Phys. Lett. 94, 6849 (2003).

${ }^{21}$ T. R. Briere and A. H. Sommer, J. Appl. Phys. 48, 3547 (1977).

${ }^{22}$ J. Huang and Z. Xu (unpublished). 